accident victims don't wear seat belts, although they believe in their effectiveness to prevent injuries and have been injured through not wearing them. So what hope do we have in convincing the rest of the public to wear seat belts, short of Government legislation?

A Fraser-MoOdie

Bristol

\section{Mechanism of the asthma attack}

SIR,-The classical theory of asthma suggests that an asthma attack is due to a contraction of the bronchial musculature directly caused by chemical mediators locally liberated by sensitised bronchial mast cells following the interaction of antigen and antibody fixed to the mast cell membrane. This traditional concept has been challenged by some recent studies: (a) atropine can block the antigeninduced bronchoconstriction in asthmatic patients ${ }^{1}$; (b) vagal blockade (with vagotomy, cooling, or atropine) markedly reduces the bronchoconstriction in experimental asthma in allergic $\operatorname{dogs}^{2} ;(c)$ in guinea-pigs sensitised to the tracer protein horseradish peroxidase and challenged with an aerosol of the antigen a significant diminution of airways resistance has been observed, although it was not possible to demonstrate any penetration of the tracer protein beyond the basement membrane of the bronchial epithelium. ${ }^{3}$

Two hypothetical suppositions conflicting with the classical theory follow from a consideration of these findings. Firstly, that the bronchoconstriction characteristic of the asthma reaction is mainly due to a vagal reflex triggered by chemical mediators liberated by the sensitised mast cells on contacting the antigen. Secondly, that the interaction between the antigen and the antibody fixed to the mast cells, with the resulting liberation of chemical mediators, occurs (at least in the first phase of the asthma reaction) in the bronchial epithelium, as this, because of its firm attachments, does not allow the passage of the antigen molecules as far as the subepithelial connective tissue where, according to the traditional concept, the antigen-antibody interaction has hitherto been thought to occur.

In the hope of verifying the possible presence of mast cells in the bronchial epithelium, I have

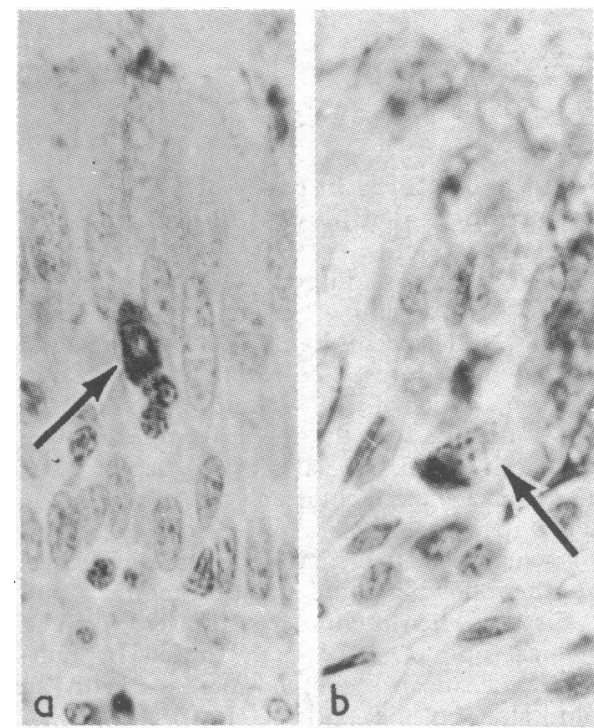

Sections of biopsy specimens showing: (a) granulated mast cell (arrowed) in bronchial epithelium of chronic bronchitis; and (b) degranulated mast cell (arrowed) in bronchial epithelium of asthmatic patient $(\times 500)$. examined sections of biopsy specimens obtained from the bronchi of chronic bronchitics and asthmatics and stained by a selective method for mast cells (alcian blue $8 \mathrm{GX}$ at $\mathrm{pH} 0 \cdot 2$ after permanganate oxidation). In all cases I have observed the presence of scattered mast cells among the epithelial cells and at the surface of the epithelium. These cells were rich in granules in chronic bronchitics and in asthmatics in remission, while they were practically degranulated and therefore often hardly identifiable in asthmatics in the active phase (see figure)

These findings suggest that the prime mover in the chain of events leading to an asthmatic crisis is situated in these intraepithelial mast cells, degranulation of which liberates histamine, which, stimulating the intraepithelial lung irritant receptors, causes a reflex vagally mediated bronchoconstriction. ${ }^{4}$ The constriction of the bronchial wall stimulates in turn, through a mechanism of positive feedback, the irritant receptors, in this way creating a vicious $\operatorname{circle}^{5}$ so that an intense bronchoconstriction could be triggered by a comparatively light stimulus.

In a second phase the damaged epithelium tends to flake off, as is often observed in bronchial specimens from asthmatics in the active phase. ${ }^{6}$ This facilitates the penetration of the antigen into the subepithelial connective tissue rich in mast cells, ${ }^{7}$ which become involved in the reaction, degranulate, and liberate chemical mediators, causing further bronchoconstriction.

\section{G Salvato}

Division of Medicine

Provisional General Hospital,

1 Yu, D Y C, Galant, C P, and Gold, W M, fournal of Applied Physiology, 1968,32823

Gold, W M, Kessler, G F, and Yu, D Y C, fournal of Applied Physiology, 1972, 33, 719 .

Richardson, J B, et al, fournal of Allergy and Clinical Immunology, 1973, 52, 172.

Nadel, J A, Archives of Internal Medicine, 1973, 131, 83.

iddicombe, J G, in Bronchitis $I I I$, ed by N G M Orie and $R$ van der Lende. Assen, Royal Vangorcum, Salvato, G, Thorax, 1968, 23, 168

Salvato, G, International Archives of Allergy, 1961, 18, 348.

\section{Sodium valproate and platelet function}

SIR,-We have read with great interest the letter from Dr S G N Richardson and others (24 January, p 221). The minimal platelet dysfunction which they observed in vitro after incubation of citrated plasma with sodium valproate and the absence of significant effects in 23 patients taking sodium valproate do not agree with our results.

Examination of coagulation factors and platelet function tests were carried out on 20 children with seizures. The patients were under treatment with sodium valproate and the effectiveness of administration was ensured by determination of serum levels of the drug. In the five patients in whom coagulation studies gave normal results before treatment was started abnormalities were found during treatment in tests which included thrombelastography, ${ }^{1}$ platelet adhesiveness, ${ }^{2}$ retention, ${ }^{3}$ spreading, ${ }^{4}$ thrombin-induced aggregation, ${ }^{5}$ bleeding time, ${ }^{6}$ platelet count, and prothrombin consumption. Because of these findings we investigated 15 further patients who had been receiving sodium valproate for periods ranging up to two years; six of them had developed clinical signs of haemorrhagic disease, including petechiae, epistaxis, otorrhagia, and prolonged bleeding afte surgery. In these 15 patients and the five previously investigated the total numbers of abnormal findings were as follows: thrombelastography, 15; platelet adhesiveness, 14 ; retention, 11 ; spreading, 10 ; thrombin-induced aggregation, 10 ; bleeding time, 6 ; and platelet count, 7. Partial thromboplastin time (2), Quick's prothrombin time (5), and prothrombin consumption (4) were decreased in some patients.

Our in-vitro investigations with platelet-rich plasma confirmed the assumption that sodium valproate influences platelet function, resulting in liberation of platelet factor 3 after adding adenosine diphosphate, ${ }^{7}$ decreased spreading of platelets, and inhibition of thrombin-induced aggregation. Furthermore, we have found that thrombin-induced lipid peroxidation ${ }^{8}$ in platelets is inhibited by sodium valproate. To explain this last observation we postulate that sodium valproate may have an antithrombotic effect similar to that of acetylsalicylic acid. Inhibition of lipid peroxidation was also observed in normal adults after ingestion of sodium valproate.

It is our clinical impression that platelet dysfunction caused by sodium valproate cannot be ruled out with certainty by determination of the bleeding time and platelet count. According to our results thrombelastography appears to be a more reliable method of excluding haemorrhagic side effects of sodium valproate.

It should be emphasised that some of our patients were receiving other convulsive drugs in addition to sodium valproate-for example, primidone, ethosuximide, and phenytoin. In patients who were treated with these drugs alone platelet function tests gave abnormal results only rarely.

H voN Voss C PETRICH

D KaRCH

H-U SCHULZ U GÖBEL

Universitäts Kinderklinik,

II Medizinische

Medizinischen Klinik der

Lübeck

Federal Republic of Germany

Hartert, H, Deutsches Archiv für klinische Medizin, 1952, 199, 284 .

Niessner, H, Thrombosis et Diathesis Haemorrhagica, 1975, 27, 434

Breddin, K, Thrombosis et Diathesis Haemorrhagica,

1964, 12, 269.
Breddin, K, Blut. Zeitschrift für Blutforschung, 1968, 18, 84.

5 Born, G V R, Nature, 1962, 194, 927.

vy, A C I, et al, fournal of Laboratory and Clinical Hardisty, R M, et al, British fournal of Haematology, 1965, 11, 258

Stuart, M J, et al, New England fournal of Medicine,
1975, 292, 1310 .

\section{Death from asthma}

SIR,-In 1786 William Withering sen wrote: "However distressing the disease [asthma] may be at the time it does not cut short the normal period of Life."1 In the nineteenth century Oliver Wendell Holmes in America called spasmodic asthma "a slight ailment that prolongs longevity"' and at about the same time the not less famous Trousseau bestowed on the disease the accolade "le brevet de longue vie."3 In 1906 Sir William Osler maintained that "death during the attack is unknown."4

I was reminded of these famous sayings when I read the excellent and timely paper by Dr J B Macdonald and others (19 June, p 1493). It seems that the misstatements by the above three great men, excusable at their time, are still in the minds of some doctors today.

I believe that it is inexcusable to discharge an asthma patient from hospital without a follow-up period of at least five years or, even worse, not to refer him or her for specialist supervision at all. The admirable "Edinburgh scheme" referred to by the authors-that is, the possibility of self-referral to hospital and 